\title{
Juridical Review of Medical Notes Therapeutic Transactions on Medical Malpractice
}

\author{
Sinatra Gunawan ${ }^{1,2}$ \\ 1.School of Law, Merdeka Malang University, Terusan Dieng Street, PO Box 65146, Malang, Indonesia \\ 2.School of Law, Trisakti University, Kyai Tapa Street, PO Box 11440, Jakarta, Indonesia
}

\begin{abstract}
A medical certificate is an official letter that contains an explanation of a person's condition or something that the doctor made with his competence and part of the doctor's comprehensive task on therapeutic transactions. Alliances occurring include verbintenis inspanning. Problems in Indonesia for cases of ethical or juridical malpractice are not recorded in detail and official. The purpose of this study is to investigate the actions of doctors issuing medical certificate that results in harm with the element of intentionality. And it is against the law of the malpractice category. The approach used in this research is normative juridical method using analytical descriptive type specifications. Cases are taken randomly from public legal materials. Cases are analized logically, normatively and qualitatively. The results showed that Law No. 29 of 2004 on Medical Practice, and Regulation of the Minister of Health No. 2052 of 2011 on Medical Practice, Code of Medical Ethics year 2012, as well as Law No. 8 of 1999 on Consumer Protection have not regulated specifically about medical certificate including medical malpractice. A legal product is needed that provides legal protection for doctors and patients so that it can distinguish the medical certificate as a criminal act or a violation of ethics.
\end{abstract}

Keywords: Medical Note, Legal Protection, Malpractice.

DOI: $10.7176 / \mathrm{JLPG} / 107-07$

Publication date:March $31^{\text {st }} 2021$

\section{Introduction}

Article 1 paragraph 3 of the 1945 Constitution mentioned: "The State of Indonesia is a state of law." (Constitution of the Republic of Indonesia, 1945), the statement emphasizes that Indonesia is a state of law, so that the people obliged to comply. The law is a regulation on sanctions and norms that exist and is made to regulate various rights and obligations to its citizens. The purpose of this law is to avoid misbehavior and also to realize justice in the community. Every society has the right to a defense themself before the law. That means that people of different backgrounds or positions have the same position before the law.

Article $28 \mathrm{H}$ in the Constitution of Indonesia 1945 is a manifestation of the existence of a country formed to protect the interests of the community, especially in aspects of protection, fulfillment and improvement of health. It can be seen in its derivatives, namely the Law on Medical Practice, the Law on Health Workers and its implementing rules, which is the Decree of the Ministry of Health.

In recent years cases of medical malpractice have increased and become a study material. Various cases of malpractice are shown to the public through mainstream media. In contrast to the past that seemed unaffordable by law, at this time there are many legal notice, mediation and lawsuits against doctors. This is in line with the increasing public awareness toward the need for legal protection of the law, which makes the world of medicine a criminal issue not as a civil relationship.

Public and patients should be aware that doctors are human beings who can make mistakes and omissions at a certain circumstances so violations of the code of conduct is possibly happen, perhaps even to violations of legal norms. There has not been an objective and unequivocal parameter between violations of the code of ethics and violations of the law in the doctor's actions towards patients, indicating that it is necessary to meet the need for laws that can be applied in solving medical problems; this condition can be obtained by exploring the phenomena that exist in the competence and profession of medicine. It is also necessary to set the record straight about the understanding of the problem of medical malpractice where there is a confusion of understanding about not supposedly being sanctioned criminal threats but simply considered a violation of ethical norms of the profession only.

The public needs to realize that medical science is not an exact science, where in determining the diagnosis of the disease is a skill and knowledge that requires imagination after hearing the complaints of patients and making careful observations of it. The provision of a medical's note after treatment is also based on the thought of the need to the patient and related to the diagnosis.

At this time, doctors are questioning about legal protection in accordance with the mandate of Law No. 29 of 2004 Article 50 paragraph 1 (Halim 2020, p. 145), and not about the issue of legal responsibility and legal awareness of doctors in carrying out their profession. Medical malpractice is unethical act of a medical professional and results in patient loss. The provision of a medical note is the action of a medical professional, if it results in a loss it can be a malpractice because the note is related to diagnosis and therapy as well as medical 
advice.

Medical Malpractice in Indonesia becomes a news trend at this time and always talked about. Doctors who are accused of "Malpractice" are said to be "untouchable" by the rule of law due to the complexity of proving medical malpractice in law enforcement in Indonesia. In Japan there were 1,440 malpractice cases recorded during 2008 (Syah 2019, p.49). In Indonesia from 2006 to 2012 there were 182 cases of medical negligence (Tempo, 2013) In England, the development of medical law is more advanced than countries that do not adhere to the common law system, such as America. In America there are about 17,000 medical malpractice claimed each year (Forbes, 2016). Cases in Indonesia are not specifically recorded and published, possibly considering the prevailing legal system. The Indonesian legal system is a combination of several legal systems namely religious law, customary law, and Continental European State Law or Civil Law (Ishaq 2016, p. 221).

Cases of alleged negligence, doctor's misconduct, medical disputes or better known as alleged doctor malpractice are lex specialis cases so it will be difficult to be tried in a public court. A general court judge, in deciding a case, requires expert information from a doctor. Judges often have difficulty making decisions and cases will run protracted with various expert statements that can contradict each other. Medical malpractice in the examination process in court requires certainty about the existence of an element of negligence in the theory of legal liability. Furthermore, legal accountability always demands the fulfilling of elements of unlawful acts.

Examples of current cases concerning the granting of medical notes in a doctor's relationship with a patient as a transaction are the news that arises and published by the TRIBUNE dated January 10, 2018, May 18, 2020, about a medical notes written, signed and given as a letter that guarantees and gives instantaneous freedom to a corrupter such as Djoko Tjandra, Setyo Novanto, or patients during the Covid 19 Pandemic.

Investigating and analyzing the news, and putting the events of medical law in the Law on Medical Practice, Health Law, other related Laws and the Civil Code and Criminal Code, it is found to be an act that is against the law or conflicts with the applicable law. The author analyzed the Law relating to physician practice namely: Law No. 29 of 2004 on Medical Practice, Law No. 36 of 2014 on Health Workers, Law No. 44 of 2009 on Hospitals, Law No. 8 of 1999 on Consumer Protection, Law No. 19 of 2016 on Amendments to Law No. 11 of 2008 on Information and Electronic Transactions, and The Medical Code of Ethics in 2012, as well as the Medical Council Regulations of 2020.

Based on the background description, the author conducted a study with the title Juridical Review of Therapeutic Transactions of Doctor's Certificate Against Medical Malpractice.

\section{Problem Statement}

1. How is the Provision of Doctor's Certificate Called Medical Malpractice Category Of Unlawful Acts?

2. How are the Laws and Implementing Rules Governing the Provision of Doctor's Certificate?

\section{Research Methodology}

In this study, researchers used a normative legal research. The approach used is The Approach Statute and Case Approach. Researchers analyzed legal materials derived from primary legal materials, namely legislation, dogma and legal principles. Researchers also used secondary legal materials, in the form of text books, journals, thesis, or documents related to the issues discussed. In addition, tertiary legal materials are also used. Analysis of legal materials using deductive reasoning methods and presented in descriptive form. From these results are then drawn conclusions that are the answer to the problems raised in this paper.

\section{Discussion}

Human beings in their daily lives can not be separated from the interaction of fellow human beings. In human interaction is inseparable from a certain set of rules and prohibitions known as laws. Regulation is a law that is in abstracto or general norms that are generally binding and its duty is to regulate things of a general nature (Ridwan 2011, p. 129). Violations of regulations and omissions committed will be subject to sanctions.

The law in Indonesia adheres to the Continental European legal system which has principles embodied in the rules in the form of laws and is arranged systematically in certain condifications or compilations. In Indonesia also applies the customary legal system, and the religious legal system in addition to the Continental European legal system.

Indonesia adheres to the welfare stat (Halim 2020, p.49) and applies positive laws, namely current and local laws. Positive legal products include generally applicable laws (Erwin, Busroh 2012, p. 79) and regulations (regelling), or specially applicable decisions (beschikking), whose implementation is controlled by the state apparatus and the judicial world. The laws in Indonesia are complex and broad, where the elements of the law are intertwined with each other, influence each other and fill each other (Bisri 2012, p. 39). There is no law specifically for medicine. Medical law is the ius constituendum, meaning the law that is envisioned or wished for in the future.

The law has a purpose that benefits all people including patients, families of patients and doctors. The 
relationship between doctors and patients is more directed to private law because there is some kind of agreement made (Nasution 2012, p. 15), unless there is a legal event between the doctor and the patient in the form of a violation in the form of a crime.

Regulation and supervision related to medical disciplines is one of the main benchmarks in medical audits to determine doctors have committed medical errors. Medical misconduct can be proven by the Medical Committee and the Honorary Assembly of Indonesian Medical Discipline (MKDKI), so that from the results of investigations and medical audits can help law enforcement in determining the misconduct of doctor's actions.

To determine the criteria of doctors in committing medical errors, not only rely on errors in criminal law alone. Due to the criteria for determining medical errors of doctors, must first pass a series of proofs in the scope of medical disciplines and medical ethics, all of which are carried out by means of medical audits by medical organizations that control such as MKDKI and MKEK, as stipulated in Article 49 of Law No. 29 of 2004 on Medical Practice, as well as Regulation of the Minister of Health of Indonesia No. 755 of 2011 on the Implementation of Medical Committees in Hospitals. In addition, The Indonesian Medical Council Regulation Number 4 Year 2011 concerning Professional Discipline of Doctors and Dentists, is the most important and fundamental element to prove that doctors have committed medical errors (medical malpractice).

Based on data gathered from PB IDI, complaints and lawsuits against doctors in Indonesia increasing every year. In 2015, the number of lawsuits against doctors as many as 10 lawsuits increased to 30 lawsuits in 2016, 38 lawsuits in 2017, and already reached 33 lawsuits in the first half of 2018 (Media Indonesia, 2018).

The term medical malpractice became widely known in society when there were cases of arises in electronic and print media. More objectively use the term medical error, than medical malpractice, because the term medical malpractice there is no legal basis that governs both reviewed from the regulations contained in the disciplines of medical sciences, medical ethics and criminal law.

Malpractice is a foreign term and according to Daris Peter Salim in "The Contemporary English Indonesia Dictionary", means wrong deed or action. Malpractice in the English-Indonesian dictionary by John M.Echols and Hassan Sadily means the wrong way of treating patients. The scope of malpractice includes a lack of ability to carry out professional obligations based on trust (Astuti 2009, p. 212).

Medical Malpractice is the negligence of a doctor using knowledge and skill level based on the size that is prevalent among others in treating patients of standard size in the same environment (Syah 2019, p.49). It is said that the negligence of the doctor is certainly no element of intentionality, because if there is an element of deliberateness then it is not the classification of malpractice but a general criminal.

Elements of malpractice consist of the standard of the medical profession that grows from health sciences, the exist or lack of medical risks that require the help of health experts, the number of Informed Consent and or medical records, the lack of negligence in carrying out professional duties, as well as the forgiving reasons and or reasons for law-bending (Suryadhimirtha 2011, p. 20).

Discussing medical errors in medical disciplines means that the discussion has been included in the scope of medical actions of doctors and dentists to patients in accordance with therapeutic relationships based on morals and professionalism, as stipulated in the overall regulation of the Medical Council No.4 Year 2011 on Professional Disciplines of Doctors and Dentists, which expressly prohibits doctors from committing violations of the professional disciplines of doctors and dentists.

Any profession in its activities including the profession of doctor, can not be separated from the existence of a mistake in the medical action, so that if the medical error is proven, then it can be held accountable both administrative, civil and criminal law even though the fact that the medical action is based on noble devotion (officium nobile) to the patient.

In medical action by a doctor can arise a problem in the form of negligence that is then associated with criminal law. To determine the negligence that is said to be wrong, Sofyan Dahlan presented by proving with element 4 D namely: Duty, Dereliction of That Duty, Damage, and Direct Causal Relationship (Dahlan 1999, p. 63). The current example of the transactions in connection with the issuance of doctor's certificate is some news published by the print and electronic media of the Tribune such as on July 18, 2020 about a doctor's certificate to a corrupter Djoko Tjandra, dated January 10, 2018 to another corruptor named Setya Novanto, dated May 18, 2020 to the passengers of the plane during the Covid 19 Pandemic.

Reading and analyzing the news, as well as putting the events of medical law in the Law on Medical Practice, Health Law, other related Laws and the Civil Code and Criminal Code, it is found to be an act that is against the law or conflicts with the applicable law. With the case of medical error above, described that the medical profession that has scientific competence and full of devotion in carrying out medical actions, does not escape an act of wrong in providing medical actions to patients, although only provide a doctor's certificate.

From the relationship of therapeutic transactions that include verbitenis (Halim 2020 p. 97) inspanning between doctors and patients, it gives birth to the Rights and Obligations of doctors in carrying out medical actions against patients as stipulated in Article 50 of Law No. 29 of 2004 on Medical Practice. Paying attention and adhering to the law of medical practice, doctors who provide doctor's certificate obtain legal protection 
because it is included in carrying out duties in accordance with professional standards and providing medical services in accordance with professional standards. Errors in a broad sense include willfulness, negligence and accountability. These three elements are subjective elements of the requirements of criminalization or if they follow a group that incorporates the element of error in a broad sense into the sense of deliberation (strafbaar feit) as a subjective element deliberative, it is added, that the absence of forgiving reasons is also the fourth part of the error (Hamzah, 2008, pp. 111-112).

The act of providing a doctor's certificate by the doctor profession is an obligation that exists in the competence of the doctor and in accordance with the mandate of the law of medical practice. Medical notes that includes data falsification, fake letters, leaking medical secrets can directly enter the criminal realm because it is regulated in the Criminal Code. While the false medical notes given and disseminated can follow the sanctions given in the information and electronic transaction laws, and if there is a loss to the patient or who gives income to the patient, it can be used civil lawsuit Article 1365 and Article 1366 of the Civil Code. If an error occurs in the form of administration such as written inappropriate workplace then it is enough to be subject to administrative sanctions in the form of reprimands and apologies.

Provisions on doctors who commit medical errors and are proven to be immediately penalized, as promised in article 359 of the Criminal Code jo. Article 361 of the Criminal Code against the doctors who are accused, is an incorrect understanding. Because understanding this depends on the question of whether in doing this the doctor has mistakes and types of mistakes made. No conviction if there is no wrongdoing (geen straf zonder schuld; actus non facit reum nisi mens sist rea) is the basic cause of accountability in criminal law.

In the field of criminal law, the principle of lex specialis derogat legi generali is mentioned in Article 63 paragraph (2) of the Criminal Code which specifies that, "If an action is included in a general criminal provision, but also included in a special criminal provision, then only that particular one is applied". The law governing the profession of doctors, there is not one article that states that because of the negligence of a health worker including a doctor can be convicted, and the law has a special rule (lex specialis). A new doctor can be criminalized or criminalized if his actions were intentionally done, all the provisions of his criminal mention must be with the element of intentionality. No doctor will do anything intentionally in doing his profession to a patient until they can take their lives.

The concept of criminal liability, with regard to the mechanism that determines the convicted maker, so that it is especially influential for the judge. The judge should consider the whole aspect, both positively and negatively formulated. The judge should consider it, even if the Prosecutor does not prove it. Conversely, when the defendant submits a defense based on a reason that erases the error, then the judge is obliged to enter the matter deeper (Huda 2008, p. 67).

Medical records are files containing records and documents about patient identity data, examinations, treatments, actions and other medical services that have been provided to patients (Ta'adi 2012, p. 40). Medical records are stipulated in Regulation of the Minister of Health No. 269 of 2008 concerning Medical Records. Doctor's certificate is part of the medical record because if the doctor gives a sick certificate or a certificate free of covid 19 or a letter of return to work or fitness to work, then the doctor is not prohibited from recording manually in the medical record.

The existence of a doctor's certificate is necessary when reviewed in terms of the implementation of doctor's practice as well as from legal aspects in health care facilities and in therapeutic transactions under certain circumstances. From the view of the legal aspect, doctor's certificate can be used as a guide or evidence in legal events.

As a medical professionalism, doctors must be honest and trustworthy in providing medical information, both in oral and written form; this is in accordance with the mandate of the Medical Code of Ethics Year 2012 Article 7 reads " every doctor is obliged to give a certificate and opinion that has been self-examined the truth", and the mandate of the Medical Council Regulation No. 74 of 2020 Article 8 paragraph 2 point b reads "give, every sick certificate with the principle of prudence and high accountability (Code of Medical Ethics,2012)(Medical Council Regulation Number 74,2020).

The obligation of the doctor to carefully read every document to be signed so that there is no misexplanation that can be misleading in making medical information in the form of writing (hardcopy). What about the provision of health certificate, return to work certificate and certificate can work? This can be answered by the argument that the doctor who determines the patient is sick and not, the doctor has the authority, then the doctor also gives a certificate according to the patient's needs. The thought of the doctor giving a certificate can not be intervened by anyone because the doctor who directly confronts the patient, the doctor who knows the psychic and physical state and needs of the patient.

Sanctions violations that can be imposed for violations of the unaniable medical record facility according to the Medical Records Decree Article 17 is an administrative sanction, and there is no clear mention of sanctions in connection with the available or unavailable doctor's certificate. With a doctor's certificate in a medical record, the sanctions that arise can follow the sanctions in the article explaining the medical record because the doctor's 
certificate is in the medical record. In Article 79 of Law No.29 of 2004 on Medical Practice threatens the criminal sanction of imprisonment of maximum 1 (one) year or a maximum fine of Rp. 50,000.000,- (Fifty million rupiah) any doctor or dentist who intentionally does not put up a nameplate, does not make medical records and does not meet obligations. This is not touched directly by making a medical certificate because the medical certificate is an optional but has a strong meaning.

Unregulated provisions of violations of the secret position of doctors in the Medical Records Decree and the Law on Medical Practice as a special provision (lex specialis), then the provisions used in case of violations are based on the Criminal Code as a general provision (lex generali). And can be used criminal sanctions ensnaring doctors, namely in Article 322, Article 378, Article 372, Article 263, Article 266 of the Criminal Code in connection with the doctor's certificate and the Civil Code Article 1365,.

As long as health workers and doctors work according to the standards of the code of professional ethics and operational standards of procedures in the health service, it will get legal protection and will not be criminalized. One of the obligations of doctors in therapeutic transactions is to make a sick or healthy certificate and or return to work and or fit to work correctly and responsibly with a prudence and high ailments. Therefore, the incompatibility of the certificate lyses the imposition of administrative sanctions, and may be subject to civil sanctions, as well as criminal sanctions.

The position of the doctor's certificate in therapeutic traction can be a means of evidence in the form of a letter (if given out of court), and expert information (if submitted in a court hearing) but does not have binding evidentiary powers because the judge is free to assess the power of proof. Doctor's letter can be used as evidence or guidance tool in accordance with legal needs.

During the relationship between the doctor and the patient, the doctor makes a medical note containing medical records. The presence of a medical notes in terms of medical practice is very important, both for health care facilities, companies, employers, insurance and patients themselves. A medical notes is tangible evidence describing one or more of the existing physician-patient relationships such as diagnosis, medical action, medical outcomes, health estimates after medical action and all medical procedures are administered.

Medical note as a legal evidence that is seen in terms of formil and materil must be included in the medical record. In addition to the obligation to comply with the provisions of KUHAP also adhere to the standard operating standards of standard procedures that apply generally in the field of medicine. Doctor's certificate is seen as functioning from the legal side can be used as evidence in the process of law enforcement, examination of medical ethics and medical discipline. Especially in the process of law enforcement, a doctor's certificate in the medical record can be accepted as a means of evidence in the process of resolving a lawsuit, namely to determine whether or not the doctor is guilty in a legal conflict. For example, giving a letter of rest to a corruptor so as not to attend a court hearing. Another example is providing a covid-free health letter so that patients can work again but have a risk of covid 19 transmission.

Doctors who make medical note in front of the trial by the judge will be asked to provide information, this information is categorized as "expert proof of information" based on Article 186 KUHAP. KUHAP distinguishes expert information given outside the trial indirectly (in written form) and information given directly before the trial by an expert in this case the doctor. Distinction as a "proof of expert information" and as a "letter proof tool". Doctor's certificate in the form of written files or computer files can be used for written evidence to solve legal, discipline and ethical problems. In fact, a doctor's certificate is data that can be used for various purposes and if it is confidential, in the release of information, use or exposure of data for various interests, it is necessary to pay attention to the legal impact.

In the event of the issuance of a doctor's certificate made by the doctor including unlawful acts, there has not been found a special governing article that describes malpractice. Because the Law does not regulate the article on the understanding of malpractice (Suryadhimirtha 2011, pg 19), especially about doctor's certificate, the author cites the views of legal experts and legal literature and compares with legal events that have occurred.

\section{Conclusion}

Medical note given by a doctor in carrying out his duties and in accordance with his competence as a medical personnel in a transaction therapeutic alliance, is an obligation. Indicated that the doctor performed malpractice by found element of intentionality then the doctor can be penalized following the article contained in the Criminal Code. Conversely, if there is no intentionality, the doctor may violate ethics and or may violate medical discipline.

The laws and implementing rules governing the granting of doctor's certificate in particular have not been found, the existing specially regulated are informant consent and medical records. If it has not been specifically regulated then the violation of a doctor's certificate can be regulated in the regulation on inform consent and medical records if it becomes an inseparable entity. 


\section{Recommendation}

The current legal vacancy is expected to be made immediately by regulations that specifically govern medical note. Regulation in the form of relevant ministries regulations that govern specifically, referring to the Law on Medical Practice and Medical Law.

\section{References}

Book

Bisri, I. (2012). "Indonesian Legal System Principles \& Implementation of Law in Indonesia”, Jakarta, Indonesia : PT Raja Grafindo Persada, p. 39.

Dahlan, S. (1999). "Health Law Signs - Signs for the Professional Doctor", Semarang, Indonesia: Undip Publishing Agency, p. 63.

Erwin, M. and, Freaddy, F.B. (2012), “Introduction to Law”, Bandung, Indonesia: PT Refika Aditama, p. 79.

Halim, A. (2020), “Amputation of the Government on the Right to Health Services", Yogyakarta, Indonesia : Publisher Total Media Creation, p. 49.

Halim, A. (2020), "Health Law and Policy Inconsistency”, Yogyakarta, Indonesia : Total Media Creation Publisher, p. 145.

Hamzah, A. (2008). "Principles of Criminal Law”, Jakarta, Indonesia: Rineka Cipta, pp. 111-112.

Huda, C. (2008). "From No Penalties Without Errors to No Criminal Accountability Without Errors", Jakarta, Indonesia : Prenada Media Group, p. 67.

Ishaq. (2016). "Fundamentals of Law”, Jakarta, Indonesia : Sinar Grafika Publisher, p. 221.

Iskandar, M.S. (2019). "Medical Malpractice Lawsuits”, Jakarta, Indonesia : Bhuana Ilmu Popular Publishers, p. 3.

Johan, B.N. (2012). “Doctor's Accountability Health Law”, Jakarta, Indonesia : PT Rineka Cipta, p. 15.

Kusuma, E.A. (2009). "Therapeutic Transactions in the Effort of Medical Services in Hospitals", Bandung, Indonesia : Citra Aditya Bakti, p. 212.

Ridwan, HR. (2011). "State Administrative Law”, Jakarta, Indonesia : Rajawali Pers, p. 129.

Suryadhimirtha, R. (2011). "Medical Malpractice Law with Cases and Solutions”, Yogyakarta, Indonesia : Total Media, p. 19.

Ta'adi. (2012). "Health Law Sanctions \& Motivation for Nurses”, Jakarta, Indonesia : 2nd Ed, Book Medical Publishers EGC, p. 40.

\section{Laws and Regulations}

Amendments to Law Number 11 of 2008, concerning Electronic Information and Transactions concerning Law Number 19 of 2016.

Approval of Medical Action, 2008, Regulation of the Minister of Health Number 290.

Constitution of the Republic of Indonesia 1945, Ministrel of law, Indonesia.

Consumer Protection, 1999, Law Number 8.

Health Workers, 2014, Law Number 36.

Hospitals, 2009, Law Number 44.

License to Practice and Implementation of Medical Practice, 2007, Regulation of the Minister of Health Number 512

Medical Practice, 2004, Law Number 29.

Medical Records, 2008, Regulation of the Minister of Health Number 269.

Minimum Service Standards in the Health Sector, 2016, Minister of Health Regulation Number 43.

Supervision in the Health Sector, 2018, Regulation of the Minister of Health Number 10.

The Implementation of Medical Committees in Hospitals, 2011, Regulation of the Minister of Health Number 755.

Code of Medical Ethics 2012

Clinical Authority and Medical Practice through Telemedicine During the Pandemic Corona Virus Disease 2019 (Covid-19) in Indonesia, 2020, Regulation of the Medical Council Number 74

Professional Discipline of Doctors and Dentists, 2011, Regulation of the Indonesian Medical Council Number 4.

\section{Online Sources}

Bazemor.N, 2016, "Does Your Doctor have Malpractice Claims How to Find Out", viewed November $10^{\text {th }} 2020$, https:/www.forbes.com/sites/amino/2016/04/19/does-your-doctor-have-malpractice-claims-how-to-findout/

Majalah Tempo, Monday, March $25^{\text {th }} 2013,2013$, viewed November $9^{\text {th }} 2020$, https://www.tempo.co/

Mediasi Harus dimanentuk dalam Kasus Malpraktik, 2018, viewed November $20^{\text {th }} 2020$, https://mediaindonesia.com/read/detail/168824-mediasi-harus-dimanentuk-dalam-kasus-malpraktik 